\title{
Biomass and nutritional evaluation of German grass (Echinochloa polystachya) cultivated on floating bed
}

MM Islam ${ }^{1,3}$, MMH Khan ${ }^{*}$, MJ Uddin ${ }^{2}$ and MJ Islam ${ }^{1}$

Affiliation: ${ }^{1}$ Department of Biochemistry and Chemistry, Sylhet Agricultural University, Sylhet, Bangladesh; ${ }^{2}$ Department of Animal Nutrition, Sylhet Agricultural University, Sylhet, Bangladesh; ${ }^{3}$ Department of Animal Resources, Doha, Qatar

\begin{abstract}
German and Napier grasses were cultivated on floating agricultural bed at the valley of Sylhet Agricultural University (SAU) to find out a suitable fodder for floating bed fodder cultivation. Later, German grass was cultivated on five floating beds at Hemupara of Jaintapur, Sylhet and also produced at land of SAU campus. German grass samples from both floating beds and land, as well as local Bermuda grass from Hemupara were evaluated for assessment of biomass production, proximate and fiber composition. There was no significant difference in length and production of German grass cultivated on floating bed and land cultivation. German grass production cost on floating bed was 2.3 $\mathrm{Tk} / \mathrm{kg}$. German grass from floating bed contained more ether extract, Ash, Neutral detergent fiber and cellulose than that from land cultivation. DM, Ash, CP, EE, CF and NFE of German grass on floating beds at Hemupara were $199.7 \mathrm{~g} / \mathrm{kg}, 20.1 \mathrm{~g} / \mathrm{kg}, 57.2 \mathrm{~g} / \mathrm{kg}, 37.2 \mathrm{~g} / \mathrm{kg}, 411.8 \mathrm{gm} / \mathrm{kg}$ and $273.9 \mathrm{~g} / \mathrm{kg}$ respectively. The fiber components of German grass on floating beds were NDF $(696.4 \mathrm{~g} / \mathrm{kg})$, ADF $(452.2 \mathrm{~g} / \mathrm{kg})$, ADL $(100.1 \mathrm{~g} / \mathrm{kg})$, cellulose $(244.1 \mathrm{~g} / \mathrm{kg})$ and hemicellulose $(352.1 \mathrm{~g} / \mathrm{kg})$. German grass can be considered as a suitable fodder for floating bed fodder cultivation when there is long term water logging as an alternative fodder production practice in Bangladesh.
\end{abstract}

Key words: floating bed, German grass, biomass production, nutritional evaluation

Bangladesh Animal Husbandry Association. All rights reserved.

Bang. J. Anim. Sci. 2017. 46 (4):249-257

\section{Introduction}

Livestock plays a vital role in agriculture of the country (Tabassum et al., 2008). Dairying in Bangladesh is a preferred option to generate income, accumulate assets and alleviate poverty (Khan et al., 2009; Tabassum et al., 2008). Livestock provides meat and milk, thus plays an important role in human health and nutrition (Chawdhury et al., 2016). The demand for meat and milk in the country are increasing by time (Huque and Sarker, 2014). Scarcity of green fodder is one of the major constrains of dairy farming in Bangladesh (Khan et al., 2009; Roy et al., 2012). In this country, there is no well-defined pasture area (Tabassum et al., 2008). Ruminants of the country mostly depend on crop residues, agro-industrial by-products, naturally grown leaves from trees and native grasses from roadside verges, aquatic plants and fallows (Roy et al., 2012; Chawdhury et al., 2016). These areas are used as pasture for all kinds of ruminants are not maintained for improving the yield for animal feed. Productivity of these pastures is low (Tabassum et al., 2008) and influenced by season and climate.
In Bangladesh, there is a requirement of 70 million metric tons of green grass for cattle feed in a year but production is only 24 million metric tons. This $60 \%$ deficit is hampering the livestock production to a great extent (Roy et al., 2012). Poor nutrition results in low production and reproductive performance, slow growth rate, loss of body condition and increased susceptibility to diseases and parasites (Khan et al., 2009; Islam et al., 2016). Due to increased pressure of human population, most of the pasture lands are being now converting to crop cultivation (Miah and Noman, 2003). Fodder cultivation is mostly limited to the large farms. Poor marginalized farmers are still not well acquainted with fodder cultivation. This is why, feed available for ruminant livestock is not sufficient in the country. In Bangladesh, most forages consumed by livestock are relatively low quality (Khan et al., 2009). Climate change acts as another barrier of sustainable livestock production in Bangladesh (Chawdhury et al., 2016). The country is one of the highest vulnerable countries in the world for climate change (UNDP, 2009). Although the country is

*Corresponding author:mehedi2001bdbd@gmail.com 
not responsible for worldwide climate change, the country people are suffering and prone to future suffering for climate change (Chawdhury et al., 2016). The country is facing flood every year at different location. Many parts of the country are waterlogged for several months every year. The peoples of the chars, haors and waterlogged areas suffer a lot mostly during monsoon to fulfill their basic needs. These peoples are generally agrarian and are either poor or very poor (Sarma, 2010). Most of them have or like to have livestock that gives them food, income and financial backup. During monsoon or flood season, their livestock suffer mostly due to shortage of food and waterborne diseases. As grazing or pasture lands become submerged under water, it limits the livestock to avail green grass. The poor residents cannot buy food for their livestock for shortage of money.

Sustainable development of the country cannot be ensured if the country people specially the poor and marginalized people's development cannot be confirmed. Among the applicable sustainability options for these people, sufficient production of livestock food, as well as proper supply of food and management to their livestock and effective institutional framework to keep the livestock safe from the climate change vulnerability (Chawdhury et al., 2016) is important. Adaptation and mitigation of the detrimental effects of extreme climates has played a major role in combating the climatic impact on livestock (Veerasamy et al., 2016) and sustainable development of the country. Government and many national and international organizations are working to upgrade their living standard mostly by adaptation and mitigation. Many researches and extension works are going on to upgrade their livelihood, educate them and to provide them strong economic background as well as to ensure their sustainable development (Khan et al., 2016; Chowdhury and Moore, 2015; BRRI, 2016). Very limited work has been done for food security of livestock to have sustainable livestock farming.

Floating bed agriculture is a locally adopted farming system in southern Bangladesh. The residents of southern Bangladesh, who face long water logging every year use to cultivate different vegetables and spices during monsoon on floating bed. This cultivation practice is a good adaptation and sustainable development practice as it was developed by the natives, gives good economic return and widely accepted by the local inhabitants and now a day practiced in many parts of Bangladesh (Chowdhury and Moore, 2015; Irfanullah et al., 2011). During monsoon, when farmers face problem of fodder shortage of their livestock, fodder production on floating bed can be a good adaptation practice. Therefore, the present research work were performed to identify suitable fodder to cultivate on floating bed; biomass, nutritional and economic evaluation of floating bed fodder production to assess it as alternative and sustainable fodder production technique.

\section{Materials and Methods}

\section{Selection of study area}

Hemupara of Jaintapur was selected as Hemu is one of the flood prone villages, where farmers are away from technology and animals are suffering from malnutrition during lean period (rainy and winter season). They need technical support to upgrade their livestock properties and to improve their socio-economic status.

\section{Selection and training to volunteer farmers}

A total of five contact farmers were selected, who have minimum five cattle, owing pond and interested to upgrade their animal management system to develop their cattle stock. A day long training program was organized for all five contact farmers.

\section{Preparation of floating bed}

A total of six floating beds were prepared for the present research work. One was at SAU campus and other five were at Hemupara. The floating beds were prepared according to Irfanullah et. al. (2011), with little modification. The size of each floating bed was about 200 square foot, but the shape of each floating bed was varied with the shape of the pond on which a bed was floated. A bamboo frame was prepared and covered with plastic net. Four pieces of mature banana plants were fixed below the bamboo frame for primary floating management of the bamboo frame. Water hyacinth was stocked on the floating bamboo frame with around one feed height to make the first layer of the floating bed. Then the top layer of floating bed was prepared with 3 inches soil and cow dung mixed.

\section{Selection of fodder and its plantation on floating bed}

An experiment was carried out on the floating bed of SAU campus to select suitable fodder for floating bed cultivation. Cuttings of Napier (Pennisetum purpureum) and German (Echinochola polystachya) grasses were 
prepared. Each cutting contained three complete internodes with four nodes. Napier was planted to one half of the floating bed and other half was planted German. Distance of one row to another was $0.5 \mathrm{~m}$, similar space was kept from one planted cutting to another. Both types of cuttings produced leaf but the Napier grass could not survive after few days during heavy rain while the German continued to live and grow on the floating bed. Thus German grass was found as suitable for floating bed cultivation. German grasses were planted on all floating bed of Hemupara with similar plantation system of floating bed in SAU campus.

\section{Care and management of floating bed} fodders

There was regular check up of the bamboo frames that were supporting the structure of a floating bed. Banana plants when available were pushing under the floating beds to maintain the floating activity of the bed if required. The beds were always kept sufficient away from the pond-bank to secure the beds from free grazing cattle or goat.

\section{Sample collection and fodder production evaluation}

German grass samples were collected from floating bed Sylhet (FBS) Campus and floating bed Hemupara $(\mathrm{FBH})$ as well as the fodder garden of Department of Animal Nutrition of Sylhet Agricultural University (Land of Sylhet Agricultural University, LS). The first harvest/cut was performed after 40-45 days of plantation. Subsequent two cuts were also performed by $40-45$ days interval. All the German grasses were harvested by cutting two inches top of the base/root. Samples from all three cuts were collected for production and nutritional evaluation. Arial part of local Bermuda grass (Cynodon dactylon) grown naturally on Hemupara (Land at Hemupara, LH) were also collected.

German and Bermuda grasses produced on 2 sqft space were taken and weighed to evaluate production performance. At the same time, lengths of 5 identical fodders from each source were measured in $\mathrm{cm}$. Then the collected fodders were shifted to Biochemistry laboratory of Sylhet Agricultural University for nutritional analysis.

\section{Economic evaluation of fodder production}

Cost of preparation of every floating bed was recorded. Total fodder production by three maturation (cut) was counted. Cost of production $(\mathrm{tk} / \mathrm{kg})$ of German grass was calculated for every floating bed. Then cost of production for every bed was averaged.

\section{Sample preparation for nutritional evaluation}

Five identical fodders of each cut were collected from each of floating bed and land cultivation, 3 of them were selected to separate leaf and stem and rest 2 were kept as whole plant for the analysis. Each of leaf, stem and whole plant sample were cut separately in pieces of less than $1 \mathrm{~cm}$ size with knife. After taking samples for dry matter and ash test, rest of the samples were dried at $105^{\circ} \mathrm{C}$ for overnight, grinded with a blender machine and kept in air tight sample bottle with proper labeling. A total of 64 fodder samples (63 German grass and 1 Bermuda grass) were checked in duplicate according to Galyean (2010) and Khan (2012).

Table 1. Length and production of different forages at different levels of cultivation

\begin{tabular}{|c|c|c|c|c|}
\hline Fodder type & Source & Cut & Length (cm) & Production (ton/acre) \\
\hline & & $1 s t$ cut & 160.5 & 8.6 \\
\hline & $F B H$ & $2 n d$ cut & 118.1 & 8.2 \\
\hline & & $3 r d$ cut & 103.1 & 8.3 \\
\hline & & $1 s t$ cut & 162.6 & 7.8 \\
\hline \multirow[t]{5}{*}{ German grass } & $F B S$ & 2nd cut & 161.3 & 7.7 \\
\hline & & $3 r d$ cut & 133.3 & 8.6 \\
\hline & & 1st cut & 168.9 & 8.4 \\
\hline & $L S$ & 2nd cut & 123.2 & 8.6 \\
\hline & & $3 r d$ cut & 108.0 & 8.2 \\
\hline Bermuda grass & $L H$ & - & 13.3 & 0.9 \\
\hline \multicolumn{3}{|c|}{ SEM } & 6.11 & 0.25 \\
\hline
\end{tabular}

FBH, Floating Bed at Hemupar; FBS, Floating Bed at Sylhet Agricultural University; LS, Land at Sylhet Agricultural University; LH, Land at Hemupara; SEM, Standard Error of Means 


\section{Determination of Proximate and fiber composition}

The proximate analysis that includes dry matter (DM), Ash, crude fiber (CF), crude protein (CP), Ether extract (EE), and Nitrogen free extract (NFE) were performed according to AOAC (1990). Fiber composition that includes neutral detergent fiber (NDF), acid detergent fiber (ADF) and acid detergent lignin ( $A D L$ ) were analyzed by the method described by Van Soest et al. (1991), Goering and Van Soest (1970) and Van Soest (1963) with some modification by Khan and Chaudhry (2010). Cellulose and hemicellulose of the fodder were calculated according to Khan (2012).

\section{Statistical analysis}

Minitab 17 was used for statistical analysis. A completely randomized design (CRD) was followed among the different floating beds for total production and length. Nutritive values were compared with German and Bermuda grass by ANOVA in General Linear Model of Minitab 17 following CRD.

\section{Result and Discussion}

\section{Fodder production and cost analysis}

Both German and Napier grew first on FBS but Napier did not survived on the FBS. Rahman et al. (2015) described Napier as mainly a highland perennial fodder. On contrary, Heuzé et al. (2016) proposed German as a low land fodder. The present study found that Napier grass is not suitable for floating bed fodder cultivation at the time when heavy rain takes place. As German grass grew well on the floating bed, it is suitable for Floating bed fodder cultivation (Figure 1).

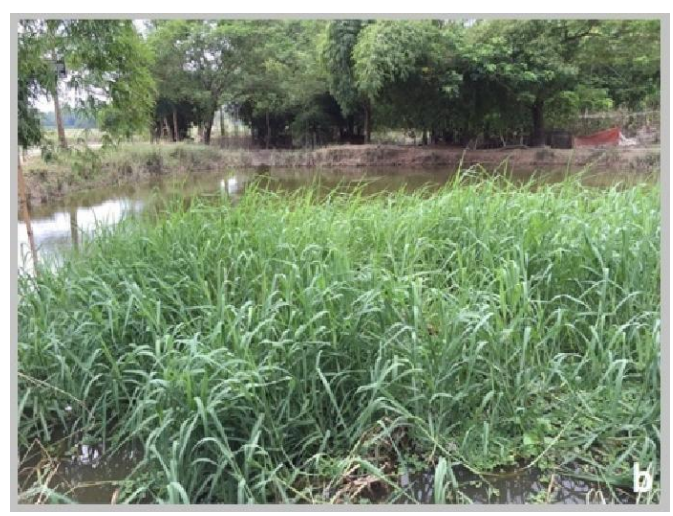

Figure 1. Fodders on a floating bed after full growth.
Table 1 shows total length and production performance of different forages cultivated on FBS, FBH, LH, and LS. Total production and length was higher (9 to 10 times, respectively) in German grass than Bermuda grass $(P<0.001)$. There was no significant difference by production between German grasses cultivated on different floating beds (FBS and $\mathrm{FBH}$ ) and land (LS) (Figure 2) though Haq et al. (2004) reported 10 times more vegetable production on floating bed than land cultivation.

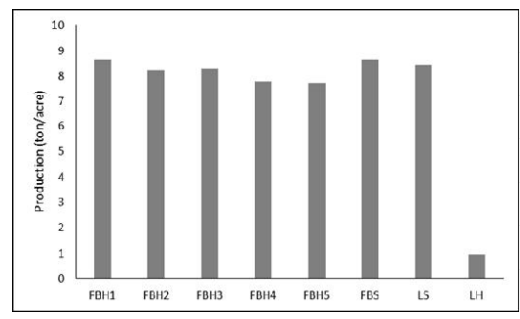

Figure 2. Comparison of production of different forages from different source.FBH: Floating bed at Hemupara, FBS: Floating bed at Sylhet Agricultural University, LS: Land at Sylhet Agricultural University, LH: Land at Hemupara

Total average height and production of German grass (138 cm and 8.1 ton/acre) on floating bed in the present research was little lower than the findings $(143 \mathrm{~cm}$ and 9.4 ton/acre) by Kanak et al. (2013) on land cultivation.

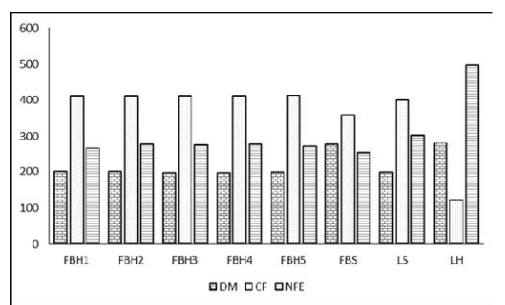

Figure 3. Comparison of DM, CF and NFE of different forages from different sources. DM: Dry matter, CF: Crude fiber, NFE: Nitrogen free extract, FBH: Floating bed at Hemupara, FBS: Floating bed at Sylhet Agricultural University, LS: Land at Sylhet Agricultural University, LH: Land at Hemupara

Production in German grass showed significant difference among different stages of maturity (cut) $(P<0.001)$. German grass production was highest $(\mathrm{P}<0.001)$ in $1^{\text {st }}$ cut, than in $2^{\text {nd }}$ and $3^{\text {rd }}$ cut. When length was increased, production was also increased for German grass significantly $(P<0.001)$. Kanak 
et al. (2013) also found increase of German grass production with the increase of length of the grasses. Better genetic variety of German grass should be ensured to cultivate on floating bed to increase the total production.

The requirement of labor cost was lower, banana plant, soil, cow dung, water hyacinth and knife were free as collected from the contact farmers own stock. After paying the cost of bamboo, net and rope, a floating bed of 200 sqft required 850.00 tk. Finally, German grass production cost on floating bed was near about $2.3 \mathrm{tk} / \mathrm{kg}$ which was lower than the cost reported by Huque and Sarker (2014) for Napier ( $3 \mathrm{tk} / \mathrm{kg}$ ) or maize (2.4 tk/kg) cultivated on land. Usually floating bed does not require any additional supplement like fertilizer or irrigation (Islam and Atkins, 2007). It helped to reduce the production cost.

\section{Proximate composition of forages}

Proximate composition of German and Bermuda grass grown on floating bed and land is shown on Table 2. There was significant difference of $C P \quad(P<0.04)$, EE $(P<0.001), \quad C F \quad(P<0.001) \quad$ and NFE $(P<0.006)$ composition between German and Bermuda grass. CP and NFE were higher in Bermuda than German grass whereas, CF and EE were higher in German grass. Significant difference were detected on $\mathrm{EE}$ $(P<0.015)$ and Ash $(P<0.001)$ in German grasses of floating bed and land cultivation. German grass from floating bed contained more EE and Ash than that from land. The $D M$ was higher $(P<0.001)$ in $F B S$ than $F B H$ whereas, CF was higher $(P<0.001)$ in $\mathrm{FBH}$ than FBS. No significant difference of the nutritional components like DM, CP, CF, EE, Ash and NFE between different floating beds at Hemupara (FBH) (Figure 3 and Figure 4).

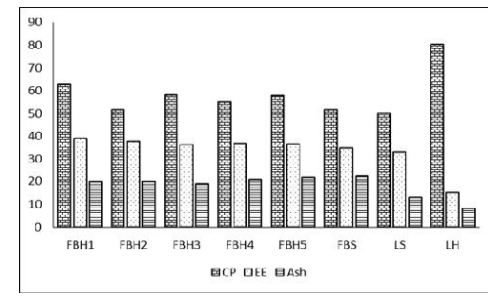

Figure 4. Comparison of $\mathrm{CP}, \mathrm{EE}$ and Ash of different forages from different sources. $\mathrm{CP}$ : Crude protein, EE: Ether extract, $\mathrm{FBH}$ : Floating bed at Hemupara, FBS: Floating bed at Sylhet Agricultural University, LS: Land at Sylhet Agricultural University, LH: Land at Hemupara
There were difference on composition of DM $(P<0.001), E E(P<0.001), C F(P<0.001)$ and NFE $(P<0.001)$ due to different cuts on German grass. DM and CF were higher in $1^{\text {st }}$ cut, then gradually reduced in $2^{\text {nd }}$ and $3^{\text {rd }}$ cut. Opposite was noticed in case of NFE which was higher in $3^{\text {rd }}$ cut, then reduced to $2^{\text {nd }}$ and $1^{\text {st }}$ cut. First cut German grass contained higher EE than $2^{\text {nd }}$ and $3^{\text {rd }}$ cut, whereas $2^{\text {nd }}$ and $3^{\text {rd }}$ cut did not have any significant difference on $E E$. It was found that DM $(P<0.001)$ and $C P(P<0.001)$ were higher in leaf than stem. It was opposite for CF $(P<0.001)$, EE $(P<0.001)$ and NFE $(P<0.001)$ i.e., $C F, E E$ and NFE were higher in stem then leaf.

German grass from floating bed contained more Ash than that of land cultivation. It may be due to the water hyacinth that was used as an important component of floating bed (Solis-Dominguez et al., 2007). Khan (2012) reported higher mineral material in leaf than stem of grasses. Due to the same reason the leaf of German grass in this work contained more Ash than stem.

\section{Fiber composition of forages}

Fiber composition of different cultivated forages in the present study has been presented on Table 3. It reveals that there were significant differences of NDF $(P<0.001)$ ADF $(P<0.001) \quad$ and Hemicellulose $(P<0.019)$ between German and Bermuda grass and were higher in German grass than Bermuda grass. NDF $(P<0.001)$ and cellulose $(P<0.003)$ in German grass were higher from floating bed than that from land and were higher Hemupara than SAU campus. There was no significant difference of fiber components among different floating beds at Hemupara.There was significant difference of NDF $\quad(P<0.05), \quad$ ADF $\quad(P<0.005), \quad A D L$ $(P<0.015)$ and cellulose $(P<0.025)$ between different cuts of German grass. NDF, ADF and ADL were highest in $2^{\text {nd }}$ cut than $3^{\text {rd }}$ and $1^{\text {st }}$ cut. Cellulose was lowest in $1^{\text {st }}$ cut and then gradually increased to $2^{\text {nd }}$ and $3^{\text {rd }}$ cut. NDF $\quad(P<0.001)$ ADF $\quad(P<0.001)$, Hemicellulose $\quad(P<0.001)$ and Cellulose $(P<0.001)$ were differing in different parts of German grass as leaf, stem and whole plant. NDF and hemicellulose were higher in leaf than stem. Reverse was found for cellulose i.e., higher $(P<0.001)$ in stem than leaf. 
Islam et al. (2017) Bang. J. Anim. Sci. 46 (4):249-257

Table 2. Proximate composition $(\mathrm{g} / \mathrm{kg})$ of different forages at different levels of cultivation

\begin{tabular}{|c|c|c|c|c|c|c|c|c|c|}
\hline $\begin{array}{l}\text { Fodder } \\
\text { Type }\end{array}$ & Source & Cut & Part & DM & Ash & CP & EE & CF & NFE \\
\hline & & & Leaf & 325.1 & 30.0 & 77.5 & 38.8 & 411.8 & 116.9 \\
\hline & & 1st cut & Stem & 164.1 & 11.2 & 40.1 & 47.6 & 405.6 & 331.3 \\
\hline & & & W. Plant & 228.7 & 24.8 & 44.4 & 41.6 & 407.9 & 252.6 \\
\hline & & & Leaf & 250.0 & 20.7 & 76.4 & 36.9 & 522.5 & 93.5 \\
\hline & FBH & 2nd cut & Stem & 141.5 & 15.7 & 47.4 & 31.9 & 336.4 & 427.1 \\
\hline & & & W. Plant & 216.6 & 19.5 & 53.2 & 36.4 & 483.1 & 191.2 \\
\hline & & & Leaf & 237.3 & 33.3 & 82.2 & 29.3 & 393.1 & 224.8 \\
\hline & & 3 rd cut & Stem & 94.5 & 9.8 & 38.6 & 44.8 & 358.3 & 454.0 \\
\hline & & & W. Plant & 139.6 & 15.9 & 55.1 & 27.7 & 387.7 & 374.1 \\
\hline & & & Leaf & 345.5 & 25.3 & 62.4 & 36.3 & 401.7 & 128.8 \\
\hline & & 1st cut & Stem & 270.4 & 18.2 & 34.6 & 45.9 & 376.8 & 254.2 \\
\hline & & & W. Plant & 290.7 & 18.3 & 53.5 & 38.0 & 389.3 & 210.2 \\
\hline & & & Leaf & 287.0 & 24.3 & 69.6 & 34.4 & 404.6 & 180.2 \\
\hline \multirow[t]{14}{*}{$\begin{array}{l}\text { German } \\
\text { grass }\end{array}$} & FBS & 2nd cut & Stem & 254.0 & 19.0 & 37.9 & 37.1 & 381.7 & 270.4 \\
\hline & & & W. Plant & 268.4 & 21.2 & 52.7 & 35.8 & 390.6 & 231.3 \\
\hline & & & Leaf & 270.5 & 26.0 & 62.4 & 37.5 & 325.4 & 278.2 \\
\hline & & $3 r d$ cut & Stem & 260.4 & 21.4 & 41.3 & 22.3 & 273.8 & 380.8 \\
\hline & & & W. Plant & 255.7 & 25.1 & 51.9 & 26.3 & 283.0 & 357.9 \\
\hline & & & Leaf & 223.0 & 17.9 & 66.8 & 31.3 & 420.5 & 240.5 \\
\hline & & 1st cut & Stem & 189.0 & 9.9 & 32.6 & 27.4 & 379.8 & 361.3 \\
\hline & & & W. Plant & 208.4 & 10.4 & 50.5 & 30.0 & 407.4 & 293.4 \\
\hline & & & Leaf & 232.6 & 19.3 & 61.1 & 33.9 & 419.4 & 233.8 \\
\hline & LS & 2nd cut & Stem & 163.2 & 9.2 & 32.4 & 36.3 & 384.4 & 374.6 \\
\hline & & & W. Plant & 201.8 & 11.1 & 58.9 & 34.7 & 391.4 & 302.2 \\
\hline & & & Leaf & 230.4 & 16.1 & 60.9 & 30.9 & 420.1 & 241.7 \\
\hline & & $3 r d$ cut & Stem & 147.9 & 9.4 & 32.4 & 35.8 & 385.5 & 388.9 \\
\hline & & & W. Plant & 192.8 & 12.0 & 57.6 & 34.9 & 389.8 & 313.0 \\
\hline \multirow[t]{2}{*}{$\begin{array}{l}\text { Bermuda } \\
\text { grass }\end{array}$} & $\mathrm{LH}$ & - & - & 280.7 & 8.1 & 80.6 & 15.0 & 119.4 & 496.3 \\
\hline & & SEM & & 5.8 & 0.8 & 1.5 & 0.6 & 5.7 & 10.1 \\
\hline
\end{tabular}

FBH, Floating bed at Hemupara; FBS, Floating bed at Sylhet Agricultural University; LS, Land at Sylhet Agricultural University; LH, Land at Hemupara; DM, Dry matter; $C P$, Crude protein; $E E$, Ether extract; $C F$, Crude fiber; NFE, Nitrogen free extract; W. Plant, Whole plant; SEM, Standard Error of Mean. 
Evaluation of German grass on floating bed

Table 3. Fiber composition $(\mathrm{g} / \mathrm{kg}$ ) of different forages at different levels of cultivation

\begin{tabular}{|c|c|c|c|c|c|c|c|c|c|}
\hline Fodder Type & Source & Cut & Part & CF & NDF & ADF & ADL & Cellulose & $\begin{array}{c}\text { Hemi } \\
\text { cellulose }\end{array}$ \\
\hline & & & Leaf & 411.8 & 697.5 & 473.1 & 63.1 & 224.4 & 410.1 \\
\hline & & 1st cut & Stem & 405.6 & 654.1 & 423.3 & 85.9 & 230.9 & 337.4 \\
\hline & & & W. Plant & 407.9 & 706.9 & 447.6 & 68.2 & 259.3 & 379.4 \\
\hline & & & Leaf & 522.5 & 715.1 & 488.3 & 114.2 & 226.7 & 374.1 \\
\hline & $\mathrm{FBH}$ & 2nd cut & Stem & 336.4 & 701.9 & 447.6 & 148.3 & 254.3 & 299.3 \\
\hline & & & W. Plant & 483.1 & 709.2 & 469.5 & 106.0 & 239.6 & 363.5 \\
\hline & & & Leaf & 393.1 & 713.3 & 481.7 & 93.5 & 231.5 & 388.2 \\
\hline & & 3 rd cut & Stem & 358.3 & 662.9 & 404.7 & 127.4 & 258.2 & 277.3 \\
\hline & & & W. Plant & 387.7 & 706.7 & 434.4 & 94.4 & 272.3 & 340.0 \\
\hline & & & Leaf & 401.7 & 679.6 & 473.4 & 60.7 & 206.2 & 412.8 \\
\hline & & 1 st cut & Stem & 376.8 & 649.1 & 430.0 & 86.2 & 219.1 & 343.8 \\
\hline & & & W. Plant & 389.3 & 668.8 & 436.7 & 72.9 & 232.1 & 363.8 \\
\hline & & & Leaf & 404.6 & 693.8 & 485.6 & 70.6 & 208.1 & 415.1 \\
\hline \multirow[t]{14}{*}{ German grass } & FBS & 2nd cut & Stem & 381.7 & 653.2 & 459.2 & 77.5 & 194.0 & 381.7 \\
\hline & & & W. Plant & 390.6 & 677.7 & 420.2 & 73.8 & 257.5 & 346.4 \\
\hline & & & Leaf & 325.4 & 717.7 & 499.8 & 71.1 & 217.9 & 428.6 \\
\hline & & 3rd cut & Stem & 273.8 & 667.2 & 408.1 & 81.2 & 259.1 & 327.0 \\
\hline & & & W. Plant & 283.0 & 702.8 & 491.3 & 76.7 & 211.5 & 414.6 \\
\hline & & & Leaf & 420.5 & 685.7 & 486.6 & 59.2 & 199.2 & 427.4 \\
\hline & & 1st cut & Stem & 379.8 & 668.3 & 418.8 & 68.1 & 249.6 & 350.7 \\
\hline & & & W. Plant & 407.4 & 681.2 & 479.8 & 62.8 & 201.4 & 416.9 \\
\hline & & & Leaf & 419.4 & 668.2 & 476.4 & 63.8 & 191.9 & 412.6 \\
\hline & LS & 2nd cut & Stem & 384.4 & 652.4 & 413.6 & 69.7 & 238.8 & 343.9 \\
\hline & & & W. Plant & 391.4 & 663.2 & 461.9 & 65.1 & 201.3 & 396.8 \\
\hline & & & Leaf & 420.1 & 668.5 & 442.3 & 66.4 & 226.2 & 375.9 \\
\hline & & 3 rd cut & Stem & 385.5 & 643.3 & 400.6 & 75.4 & 242.7 & 325.2 \\
\hline & & & W. Plant & 389.8 & 659.4 & 436.8 & 67.7 & 222.7 & 369.1 \\
\hline \multirow[t]{2}{*}{$\begin{array}{c}\text { Bermuda } \\
\text { grass }\end{array}$} & LH & - & - & 119.4 & 548.1 & 285.8 & 38.8 & 262.3 & 247.0 \\
\hline & SEM & & & 5.7 & 2.9 & 3.3 & 5.2 & 2.5 & 6.0 \\
\hline
\end{tabular}

FBH, Floating bed at Hemupara; FBS, Floating bed at Sylhet Agricultural University; LS, Land at Sylhet Agricultural University; LH, Land at Hemupara; DM, Dry matter; CP, Crude protein; EE, Ether extract; CF, Crude fiber; NFE, Nitrogen free extract; W. Plant, Whole plant; SEM, Standard Error of Mean.

\section{Conclusion}

The research indicates that German grass could be cultivated on floating bed during long waterlogged condition and/or scarcity of land for fodder cultivation. It may ensure an alternative adaptive practice for climate change and sustainable livestock farming in Bangladesh. Further research could be conducted with German grass from floating bed to evaluate in vitro degradability and gas production and animal trial to evaluate in vivo degradability, effect on animal's health, production and reproduction.

\section{Acknowledgement}

Acknowledgement to Ministry of Science and technology of Peoples' Republic of Bangladesh for funding the research 


\section{References}

AOAC (1990). Official Methods of Analysis by Association of Official Agricultural Chemists $(A O A C), 15^{\text {th }}$ ed., Washington D.C.

BRRI (2016). Adhunic Jater Dhan, Bangladesh rice knowledge bank. Retrieved December 25, 2016 from http://www.knowledgebankbrri.org/brri-rice-varieties.php

Chowdhury QMMK, M Hasan, J Ahmed, CA Shykat, MS Islam and M Hossain (2016). Impact of climate change on livestock in Bangladesh: a review of what we know and what we need to know. American Journal of Agricultural Science, Engineering and Technology 3(2):1825.

Chowdhury RB and GA Moore (2015). Floating agriculture: a potential cleaner production technique for climate change adaptation and sustainable community development in Bangladesh. Journal of Cleaner Production 150:371-389.

Galyean ML (2010). Laboratory Procedures in Animal Nutrition Research. Department of Animal and Food Sciences, Texas Tech University, Lubbock. pp.1-189

Goering HK and PJ Van Soest (1970). Forage fibre analysis, Agriculture Hand book, US Department of Agriculture.

Haq AHMR, TK Ghosal and P Ghosh (2004). Cultivating wetlands in Bangladesh. Lesia Magazine, 20 (4): 18-20.

Heuzé V, G Tran, S Giger-Reverdin and F Lebas (2016). German grass (Echinochloa polystachya). Feedipedia, a programme by INRA, CIRAD, AFZ and FAO. Retrieved 24 December, 2016 from http://www.feedipedia.org/node/449

Huque KS and NR Sarker (2014). Feeds and feeding of livestock in Bangladesh: performance, constraints and options forward. Bangladesh Journal of Animal Science 43(1): 1-10.

Irfanullah HM, MAK Azad, M Kamruzzaman and MA Wahed (2011). Floating gardening in Bangladesh: a means to rebuild lives after devastating flood. Indian Journal of Traditional Knowledge 10(1):31-38.

Islam MS, NR Sarker, MOA Rahman, MA Habib, KT Islam and JS Khanam (2016). Study on the Comparative Economic Analysis of Fodder Production with Rice at Milk Pocket Areas of Bangladesh. International Journal of Agriculture Innovations and Research 4(6): 1174-1177.

Islam T and P Atkins (2007). Indigenous floating cultivation: a sustainable agricultural practice in the wetlands of Bangladesh. Development in Practice 17:130-136.

Kanak AK, MJ Khan, MR Debi, MK Pikar and M Akter (2013). Nutritive value of three fodders species at different stages of maturity. Bangladesh Journal of Animal Science 41(2): 90-95.
Khan MJ, KJ Peters and MM Uddin (2009). Feeding strategy for improving dairy cattle productivity in small holder farm in Bangladesh. Bangladesh Journal of Animal Science 38(1\&2):67- 85 .

Khan MMH (2012). Novel Supplements to Improve Utilization of Low Quality Forages in Ruminants. Muktodesh Prokashon, Islami Tower, 11/1 Banglabazar, Dhaka-1100, Bangladesh.

Khan MMH and AS Chaudhury (2010). Chemical Composition of Selected Forages and Spices and the Effect of These Spices on In vitro Rumen Degradability of Some Forages. AsianAustralian Journal of Animal Science 23(7):889-900.

Khan S, MA Javed, N Jahan and FA Manan (2016). A Short Review on the Development of Salt Tolerant Cultivars in Rice. International Journal of Public Health Science 5(2):201-212.

Miah MD and MK Noman (2003). Farmer's preferences and indigenous practice of fodder trees in Comilla flood plain area of Bangladesh. SAARC Journal of Agriculture 1:21-32.

Rahman MZ, MY Ali, MF Afroz, MR Karim and MAI Talukder (2015). Effect of intercropping on high yielding fodder production in bathan areas of Sirajgonj district. Bangladesh Journal of Animal Science 44(1):21-25.

Roy BK, NR Sarker, MK Alam and KS Huque (2012). Existing production and marketing system of fodder under Meherpur district as livelihood activity. Bangladesh Journal of Livestock Research 19(1-2):24-32.

Sarma PK (2010). Scenario of haor vulnerabilities and other obstacles for sustainable livelihood development in Nikliupazila. Journal of Bangladesh Agricultural University 8(2):283290.

Sejian V, JB Gaughan, B Raghavendra and SMK Naqvi (2016). Impact of climate change on livestock productivity.Feedpedia, Broadening Horizons $\quad N^{\circ} 26, \quad$ Feb-16 https://www.feedipedia.org/content/impactclimate-change-livestock-productivity

Solís-Domínguez FA, MC González-Chávez, R Carrillo-González and R Rodríguez-Vázquez (2007). Accumulation and localization of cadmium in Echinochloapolystachya grown within a hydroponic system. Journal of Hazardous Materials 141:630-636.

Tabassum N, MR Uddin and U Gim (2008). Prospects of Triticale as Fodder and Feed in Farming of Bangladesh. Korean Journal of Agricultural Science 35(1):101-108.

UNDP (2009). Views of Bangladesh on climate change and its possible security implications. United Nation Sustainable Development Program (UNDP). Retrieved December 23, 2016 from https://sustainabledevelopment.un.org/co tent/dsd/resources/res_pdfs/ga-64/cc inputs/Bangladesh_CCIS.pdf 
Van Soest PJ (1963). Use of detergents in the analysis of fibrous feeds. 2. A rapid method for the determination of fiber and lignin. Journal of the Association of Official Agricultural Chemists 46:829-835.
Van Soest PJ, JB Robertson and BA Lewis (1991). Methods for Dietary Fiber, Neutral Detergent Fiber, and Nonstarch Polysaccharides in Relation to Animal Nutrition. Journal of Dairy Science 74:3583-3597. 